Original article

\title{
Relation between climatic factors, diet and reproductive parameters of Little Terns over a decade
}

\author{
Jaime A. Ramos*, Patrícia Pedro, Antonio Matos, Vitor H. Paiva \\ Marine and Environmental Research Center (IMAR/CMA), Department of Life Sciences, University of Coimbra, Apartado 3046, 3001-401 Coimbra, Portugal
}

\section{A R T I C L E I N F O}

\section{Article history:}

Received 13 March 2013

Accepted 6 September 2013

Available online 5 October 2013

\section{Keywords:}

Little Tern

Atherina spp.

NAO

Sea-surface temperature

Estuarine seabirds

Breeding parameters

\begin{abstract}
A B S T R A C T
We used 10 years of data on clutch size, egg size and diet, and 8 years of data on timing of laying on Little Terns (Sternula albifrons) breeding in Ria Formosa lagoon system, Algarve, Portugal to assess whether diet acts as an important intermediary between climatic conditions and breeding parameters. We used Generalized Linear Models to relate (1) the relative occurrence and size of the main prey species, sand smelts (Atherina spp.), with environmental variables, a large-scale climate variable, the North Atlantic Oscillation (NAO) index, and a local scale variable, the sea-surface temperature (SST), and (2) the respective effects of sand smelts relative occurrence, NAO index and SST on Little Tern breeding parameters. The diet of Little Terns was dominated by sand smelts, with a frequency occurrence of over $60 \%$ in all years. The winter SST (February) was negatively associated with the relative occurrence of sand smelts in the diet of Little Terns during the breeding season which, in turn, was positively associated with Little Tern clutch size. Our results suggest that negative NAO conditions in the Atlantic Ocean, often associated with rougher sea conditions (greater vertical mixing, stronger winds and lower SST) were related with earlier breeding, and lower SST in the surroundings of the colony during winter-spring favour the abundance of prey fish for Little Terns as well as their reproductive parameters. Climate patterns at both large and local scales are likely to change in the future, which may have important implications for estuarine seabirds in Southern Europe.
\end{abstract}

(c) 2013 Elsevier Masson SAS. All rights reserved.

\section{Introduction}

The distribution and abundance of prey fish for marine top predators is largely determined by climate and oceanographic conditions, which therefore influence prey availability to top predators such as seabirds (Aebischer et al., 1990; Furness and Tasker, 2000). Marine birds are therefore of potential use as sentinels to identify changing states in their prey populations and environmental conditions (Piatt et al., 2007 but see Grémillet and Charmantier, 2010). During the breeding season coastal tern species such as small terns of the genus Sterna and Sternula are particularly sensitive to changes in their prey distribution and abundance, because they have a very restricted foraging range and need abundant food resources very close to the colony in order to breed successfully (Furness and Camphuysen, 1997; Furness and Tasker, 2000).

\footnotetext{
* Corresponding author. Tel.: +351 239855771; fax: +351 239855789.

E-mail addresses: jramos@uc.pt (J.A. Ramos), patr.pedro@gmail.com (P. Pedro), antoniossomatos@gmail.com (A. Matos),vitorpaiva@uc.pt (V.H. Paiva).
}

Marine climate conditions are closely related to large-scale atmospheric phenomena, of which, the North Atlantic Oscillation (NAO) index is one of the best known. The NAO refers to a northsouth alternation in atmospheric mass between the subtropical Atlantic and the Arctic (Hurrell et al., 2003) and induces changes in surface temperature, precipitation and storm tracks over the North Atlantic and Europe (Pinto and Raible, 2012; Stenseth et al., 2003). During the positive phase of the NAO index the westerly winds strengthen and move northwards, inducing increased precipitation and sea-surface temperature in northern Europe and opposite conditions in Southern Europe. During the negative phase of the NAO the storm track is diverged towards southern Europe, leading to an increase in warm conditions, windspeed and vertical water mixing along the Iberian Peninsula and in Southern Europe (Pinto and Raible, 2012). Local climatic conditions are influenced by the NAO index, and for the Iberian Peninsula there is usually a negative relationship between NAO and sea-surface temperature (SST) (Báez et al., 2013 and references therein), although local climatic conditions cannot always be clearly predicted by the NAO (Becker and Pauly, 1996). Recent studies show an effect of NAO on life-history traits of North Atlantic seabirds including breeding success (e.g. Frederiksen et al., 2004; Wanless et al., 2005) and annual survival 
(e.g. Grosbois and Thompson, 2005; Votier et al., 2005). However, all studies to date have dealt with pelagic seabirds, mostly in Northern Europe, and there is virtually no data on the NAO effects for seabirds in Southern Europe, particularly for coastal/estuarine seabirds (breeding and foraging in estuarine areas and along the coast, mostly up to $5 \mathrm{~km}$ offshore) such as the Little Tern Sternula albifrons.

Breeding success may be of limited value as a response variable to assess the influence of climate and oceanographic conditions for estuarine terns, because several studies indicate that factors such as predation and anthropogenic disturbance are often more important in explaining variability in breeding success than changes in prey abundance (Holloway, 1993; Medeiros et al., 2007 and references therein, but see Dänhardt and Becker, 2011). However, other breeding parameters such as timing of laying and clutch size are less influenced by predation, and are positively correlated with breeding success and also influenced by climate and oceanographic conditions (Ramos et al., 2002; Monticelli et al., 2007; Wanless et al., 2009). Therefore, they are likely to be more adequate response variables for estuarine seabirds such as Little Terns, when assessing the influence of environmental factors such as climate and prey abundance on reproductive parameters.

Catry et al. (2006) showed that adult Little Terns in the Ria Formosa lagoon system, Algarve, Southern Portugal, feed mainly on the two most abundant prey present in the lagoon: sand smelts (Atherina spp.) and gobies (Pomatoschistus spp.). As these two prey species explained the main differences in diet among years, Catry et al. (2006) suggested that diet composition of adults Little Terns would be a reliable indicator of the relative abundance of these two fish species in the lagoon system. Paiva et al. (2006a, 2006b) showed that sand smelts are more profitable than gobies, because, although the energetic content of both prey is similar, sand smelts provide more energy yield per unit foraging effort due to its significantly larger size. Therefore, the abundance of sand smelts should have an important influence on Little Tern breeding parameters, but this was not examined. We anticipate that oceanographic conditions may influence the abundance of sand smelts, which in turn will influence timing of breeding and clutch size of Little Terns. This is expected, because the nesting season of terns (Safina et al., 1988), including Little Terns (Catry et al., 2006) and the sister species Least Tern Sternula antillarum (Zuria and Mellink, 2005) has been demonstrated to coincide with peak prey fish abundance.

We used 10 years of data on clutch size, egg size and diet and 8 years of data on timing of breeding of Little Terns to evaluate whether diet acts as an important intermediary between climatic conditions and breeding parameters. Specifically, we evaluated (1) the correlations between the relative occurrence and size of the main prey species (sand smelts) and environmental variables, a large-scale climate variable, the NAO index, and a local scale variable, seasurface temperature, and (2) the respective effects of sand smelts relative occurrence, NAO index and SST on variability in Little Tern breeding parameters (timing of laying, clutch size and egg size).

\section{Material and methods}

\subsection{Breeding parameters and diet}

We used published data for 2002-2004 (Catry et al., 2004, 2006) and collected data for 2005-2011 on timing of breeding, clutch size, egg size and diet of Little Terns breeding on the salinas (man-made salt extraction ponds) of Santa Luzia, Ria Formosa, Algarve, Portugal (N 37 $06^{\prime} 303^{\prime \prime}$; W $7^{\circ} 38^{\prime} 203^{\prime \prime}$ ), an area about $10-$ $245 \mathrm{~m}$ distance from the lagoon and $800 \mathrm{~m}$ from the sea (Fig. 1). The lagoon, where most of the terns forage (Paiva et al., 2008), is separated from the sea by sand barrier islands and, each tidal cycle, exchanges very large volumes of water with the sea through entrance channels (Newton and Mudge, 2003). Each year the whole area of the salinas was searched; some birds appeared to change the exact nesting location by at least 20-250 m, apparently determined by an increase in local vegetation cover in some areas of the salinas since 2002 (J. A. Ramos and V. H. Paiva, pers. observations).

Each nest was numbered and egg length $(L)$ and egg breadth $(B)$ were measured with callipers to $0.1 \mathrm{~mm}$, and volume was calculated using the formula: $V\left(\mathrm{~cm}^{3}\right)=K \times L \times B^{2}$, where $K=0.4866$ (Coulson, 1963). The nesting area and all nests were visited every 2-5 days and daily between 13 and 17 May to ascertain whether nests were initiated in the first or second 15-day period of May. From 2005 to 2011 we stopped searching the nesting area by 3-15 June, because previous years showed that very few clutches were laid after this period (replacement clutches were not considered). Clutch size and egg size were calculated using data from complete clutches only. To prevent pseudo-replication problems (Hurlbert, 1984) in egg measurements data we first calculated the mean for each clutch and then the annual mean of all clutches. Visits to the nesting areas lasted between 10 and $20 \mathrm{~min}$ and did not seem to cause undue disturbance, as birds resumed incubation soon after we left the areas (Catry et al., 2004).

In our study area Little Terns regurgitate along the water line of the ponds while resting, and to ensure that pellets were collected from many different individuals this whole area was searched. Pellets were collected from 2 May to 15 June (the main laying season of the Little Terns) and stored in individual paper bags for later examination in the laboratory. There, hard parts in the pellets, mainly sagittae otoliths, were separated from other remains and identified to the lowest taxonomic level possible (Catry et al., 2006) with the help of our own otoliths reference collection and identification guides (Nolf, 1985; Härkönnen, 1986; Tuset et al., 2008). Diet composition of adult Little Terns was expressed as frequency of occurrence, calculated as the number of pellets with a given prey type. We used this measure, because it enables a reliable comparison among years; most of the pellets contained either sand smelts or gobies and the other species were present at much lower frequencies, with only one otolith/pellet for virtually all pellets (Catry et al., 2006). An assessment of diet using pellets may be biased, particularly towards smaller otoliths, largely due to the differential digestibility of otoliths of the various prey items. However, it allows reliable comparisons among years (Duffy and Jackson, 1986; Catry et al., 2006), and we were interested on the annual variation in the relative importance of the most important prey items.

\subsection{Environmental variables}

We used the Gibraltar minus Iceland version of the NAO index (Jones et al., 1997), as this encompasses the Algarve, southern Portugal (downloaded from http://www.cru.uea.ac.uk/ timo/ datapages/naoi.htm). We used IGOSS (Integrated Global Ocean Services Systems, Reynolds et al., 2002) mean monthly SST blended from ship, buoy and bias-corrected satellite data (available from http://iridl.ldeo.columbia.edu/SOURCES/.IGOSS) for the location of $7^{\circ} 5^{\prime} \mathrm{W}$ and $36^{\circ} 5^{\prime} \mathrm{N}$, which is the closest marine area to the salinas of Santa Luzia available in the site (Fig. 1). This SST should provide an indication of inter-annual variation in sea-surface temperature affecting the lagoon of Ria Formosa and the immediate adjacent sea area where terns are observed foraging (Paiva et al., 2008).

\subsection{Data analysis}

We used Spearman correlation to assess whether each environmental variable (NAO index and local SST) and each Little Tern 


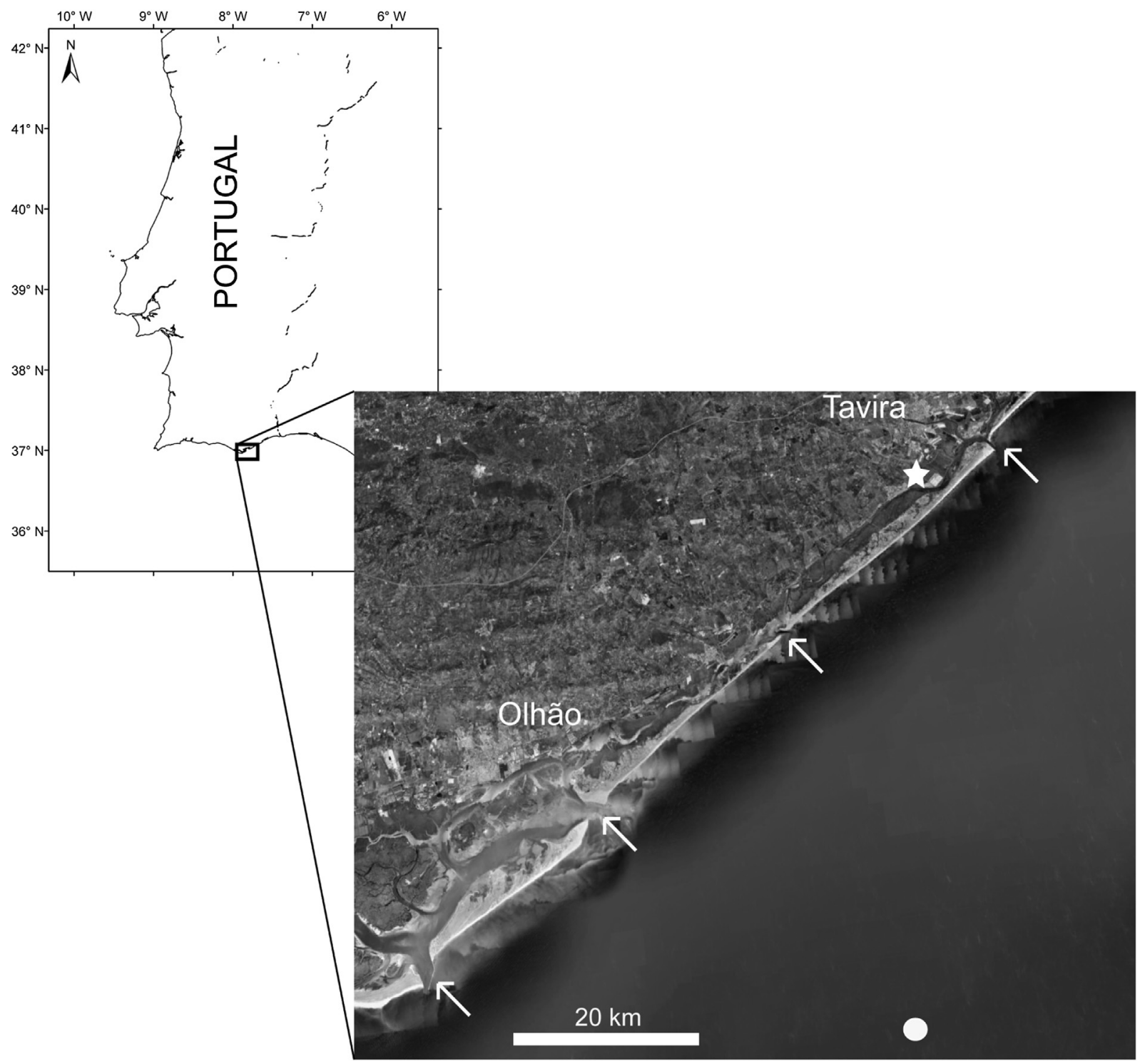

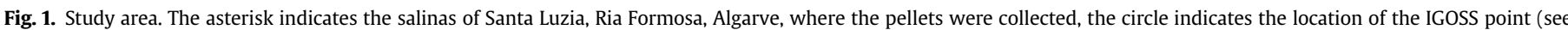
Methods), for which the sea-surface temperature was downloaded, and the arrows indicate the communication channels between the sea and the lagoon of Ria Formosa.

reproductive parameter (timing of breeding, clutch size and egg size) changed systematically throughout the study period. We related the NAO index and local SST with Little Tern breeding parameters and relative occurrence of sand smelts in their diet. The three Little Tern breeding parameters were: a) timing of breeding (assessed by the \% of total clutches initiated during 1-15 May, b) mean clutch size and c) mean egg volume. The relative occurrence of sand smelts in the diet was obtained by adding the percentages of occurrence of all prey types and scaling the \% of occurrence of sand smelts in relation to this total value, in order to obtain a better representation of the importance of sand smelts in the diet. In addition, we measured the longest otolith axis $(x)$ of sand smelts to calculate the length $\left(y=0.2148 x^{2}+21.1640 x+3.3635\right.$, in mm $)$ and the mass $\left(y=0.6726 x^{2}-0.8113 x+0.2766\right.$, in $\left.g\right)$ of ingested fishes for 2007-2011. These equations were established by J. Martins of the University of Algarve using fresh specimens captured in Ria Formosa (unpublished).

To relate environmental variables with Little Tern breeding parameters, we used the NAO index and the local SST as predictors of annual variation in the relative occurrence of sand smelts in the diet of Little Terns. Secondly, we used NAO, SST and the relative occurrence of sand smelts in the diet of Little Terns to explain variability in Little Tern breeding parameters. To evaluate the link between the relative occurrence of sand smelts in the diet of Little Terns and environmental parameters we used mean NAO and SST values for winter (Jan-Mar) and for the coldest month of the year in the Algarve (February). This is justified, because small pelagic fish in subtropical and Mediterranean areas spawn mostly during winter and early spring, when sea-surface temperature is lower (Checkley et al., 1988; Ré et al., 1990), including resident species in lagoons and estuaries such as sand smelts (Maci and Basset, 2010 and references therein). This is about 2-4 months before juvenile (0-group age class) small fishes are available for terns. To evaluate the link between Little Tern breeding parameters and environmental parameters we used the mean monthly NAO and SST values for April-May, which is the arrival and main laying season of the Little Terns.

Generalized Linear Models, using a quasi-Poisson error distribution and correcting for overdispersion, were used to relate the environmental variables with Little Tern breeding and diet 
parameters (except the mass of sand smelts, because we had only 4 years of data). The reconstructed mean mass of ingested sand smelts was compared among years (2007-2011) with a One-way ANOVA, followed by a post-hoc Tukey test, and interpreted in relation to the annual variation in NAO and SST. In addition, Chi-square tests were used to assess differences in the annual frequency of occurrence of the main prey items (sand smelts and gobies) in the diet of Little Terns. All analyses were carried out with Statistica 8 (Statsoft, Tulsa, Oklahoma, USA, 2001).

\section{Results}

\subsection{Diet and environmental factors}

The diet of Little Terns was dominated by sand smelts (Atherina spp. presumably Atherina presbyter, the most abundant fish species in the water column of Ria Formosa lagoon system, Ribeiro et al., 2008) and gobies (Pomatoschistus spp.). The frequency of occurrence of both species differed significantly among years $\left(\chi_{9}^{2}=121.41\right.$ and 120.05 , both $P<0.001$, Table 1$)$. Sand smelts were more frequent than expected in 2003 (observed $=120$, expected $=98$ ), 2005 (observed $=302$, expected $=264$ ) and 2008 (observed $=118$, expected $=106$ ), whereas gobies were consumed more than expected in 2004 (observed $=82$, expected $=29$ ) and 2007 (observed $=111$, expected $=40$ ). Typical pelagic prey such as garfish (Belone belone) and sardine (Sardina pilchardus) occurred in less than $11 \%$ of the pellets (with the exception of garfish for 2002 ). The consumption of insects increased significantly since 2002 ( $r s=0.80, P=0.005, n=10$, Table 1$)$. It is also apparent that in years with lower consumption of sand smelts birds ingested more crustaceans and other prey that we were unable to identify (Table 1 ).

The relative occurrence of sand smelts in the diet was significantly related with the mean February SST in the waters surrounding the colony (GLM: Wald $\chi^{2}{ }_{1}=3.84, P=0.049$; parameter estimate: $\beta=-0.209 \pm 0.107$, Fig. 2 ). The estimated mean mass of sand smelts ingested by adult Little Terns differed significantly among years (mean \pm SD from 2007 to $2011=3.54 \pm 0.84$, $3.72 \pm 0.81,3.77 \pm 0.87,3.40 \pm 1.06,2.40 \pm 1.68 \mathrm{~g}, n=248,270,207$, 61 and $\left.23 ; F_{4,804}=14.40, P<0.001\right)$. The post-hoc Tukey test showed that in 2011 the mean mass of sand smelts was significantly lower than in the other years. It should be noted that 2011 was the year with the highest NAO index (Fig. 3) and SST (Fig. 5) for April/ May. There was a negative but non-significant correlation between the winter NAO index (mean for January-March) and the mean SST in April/May $(r=-0.32, P=0.36)$; the SST value for 2011 was perceived as an outlier $\left(18.6{ }^{\circ} \mathrm{C}\right)$ and the correlation without this value was $r=-0.57, P=0.11$.

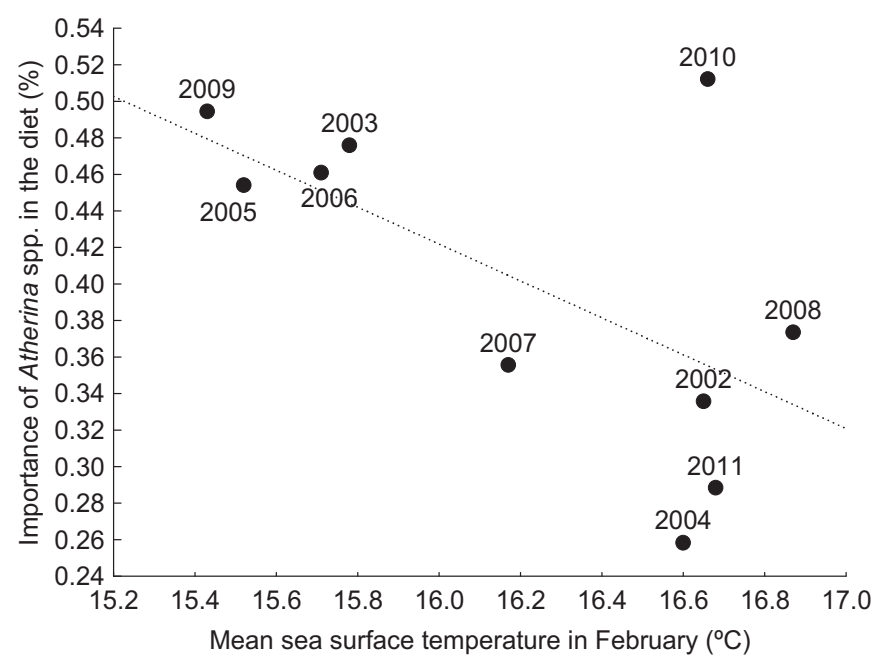

Fig. 2. Relationship between the importance of sand smelts (Atherina spp.) in the diet of Little Tern adults (=relative occurrence) in Santa Luzia, Ria Formosa, Algarve, during the breeding season and the mean sea-surface temperature in February. To obtain the relative occurrence of sand smelts in the diet of each year, the \% of occurrence of each item was added to make $100 \%$ and the value for sand smelts was scaled in relation to this total value.

\subsection{Reproductive parameters and environmental factors}

Over the study period, reproductive parameters (timing of breeding, clutch size and egg size, Table 2) and environmental variables (NAO and SST) did not change systematically $(r s, P>0.34$ for all correlations).

Little Terns began laying in the first fortnight of May for all years except 2009, but there was a strong inter-annual variation in the \% of clutches initiated between 1 and 15 May (Table 2), and this was significantly negatively related with the NAO index for April-May (GLM: Wald $\chi^{2}{ }_{1}=27.00, P<0.001$; parameter estimate: $\beta=-0.667 \pm 0.126$; Fig. 3). Thus more birds breed earlier in years when the index was lower, which corresponds to rougher spring sea conditions in the Iberian Peninsula (Pinto and Raible, 2012). Clutch size was significantly positively influenced by the relative occurrence of sand smelts in the diet (GLM: Wald $\chi^{2}{ }_{1}=4.94$, $P=0.026$; parameter estimate: $\beta=+0.764 \pm 0.344$; Fig. 4$)$.

Egg biometrics were significantly different among years (Egg length: $F_{9,389}=2.5, P=0.008$, Egg breadth: $F_{9,389}=5.0, P<0.001$, Egg volume: $F_{9,389}=4.95, P<0.001$, Table 2 ). The pos-hoc Tukey test showed that such differences were mostly attributed to the years of 2002 and 2011, when Little Terns laid smaller eggs. The

Table 1

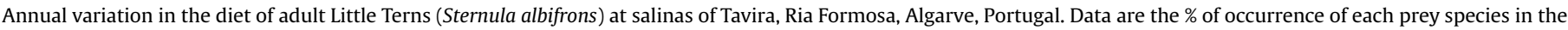
diet. The sample size ( $=$ no. of pellets) for each year is indicated in parenthesis.

\begin{tabular}{|c|c|c|c|c|c|c|c|c|c|c|}
\hline Prey species & $2002(87)$ & 2003 (130) & $2004(130)$ & $2005(351)$ & $2006(97)$ & 2007 (220) & $2008(141)$ & 2009 (113) & $2010(81)$ & $2011(46)$ \\
\hline Atherina spp. & 61.6 & 84.8 & 44.8 & 86.1 & 79.4 & 66.8 & 83.7 & 80.5 & 77.8 & 65.2 \\
\hline Pomatoschistus spp. & 34.2 & 38.1 & 63.2 & 17.1 & 36.1 & 50.9 & 38.3 & 28.3 & 35.8 & 32.6 \\
\hline Fundulus & 6.8 & 5.7 & 9.2 & 0 & 1.0 & 5.0 & 0 & 0.9 & 0 & 10.9 \\
\hline Gobius spp. ${ }^{\mathrm{a}}$ & 4.1 & 0.9 & 8.0 & 5.4 & 7.2 & 24.1 & 14.2 & 8.0 & 9.9 & 8.7 \\
\hline Belone belone & 12.3 & 10.5 & 5.7 & 0 & 4.1 & 0 & 0.7 & 1.8 & 0 & 2.2 \\
\hline Diplodus spp. & 5.5 & 3.8 & 2.3 & 8.6 & 2.1 & 4.1 & 8.5 & 13.3 & 11.1 & 8.7 \\
\hline Sardina pilchardus & 0 & 0 & 0 & 8.6 & 1.0 & 2.7 & 0 & 0.9 & 0 & 0 \\
\hline Liza spp. & 0 & 0 & 0 & 0 & 0 & 2.3 & 0 & 0 & 0 & 10.9 \\
\hline Insects & 0.1 & 0.1 & 0 & 3.6 & 9.3 & 2.7 & 9.9 & 5.3 & 8.6 & 10.9 \\
\hline Crustacea & 17.8 & 9.5 & 24.1 & 10.0 & 11.3 & 0.5 & 2.1 & 0.9 & 3.7 & 26.1 \\
\hline Other prey ${ }^{\mathrm{b}}$ & 0 & 0 & 0 & 0.4 & 0 & 1.4 & 5.0 & 1.8 & 1.2 & 10.9 \\
\hline Not identified & 41.1 & 24.8 & 21.8 & 45.7 & 19.6 & 27.3 & 27.7 & 21.2 & 3.7 & 41.3 \\
\hline
\end{tabular}

a Include Lesueurigobius friesii (3.7\% in 2010) and Parablennius spp. (0.9\% in 2007, 1.42\% in 2008).

b Include Bothus spp., Engraulis encrasicolus, Microchirus boscanion, Mullus surmuletus, Symphodus spp., Spondyliosoma spp., Serranus spp., Oblada melanura. 


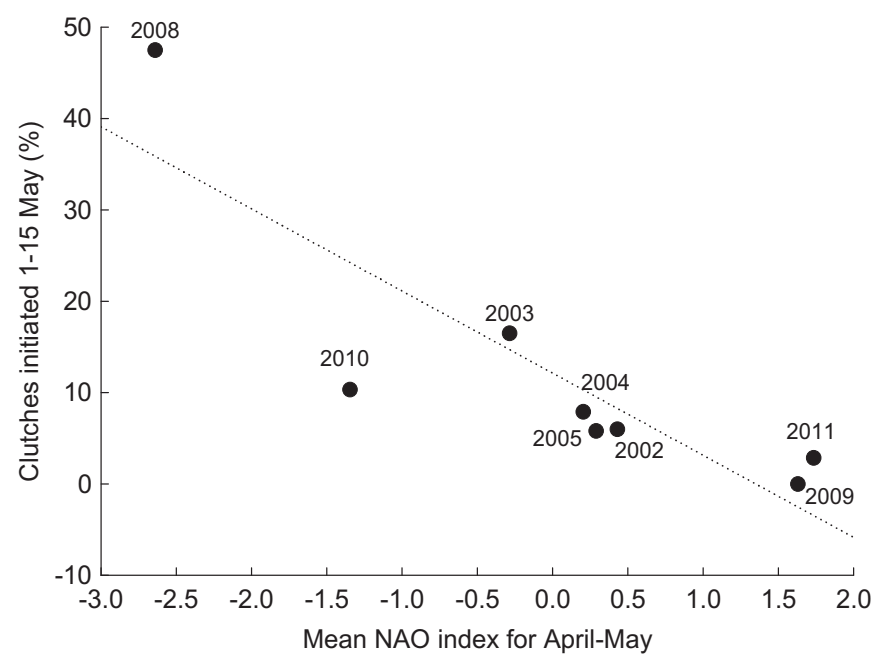

Fig. 3. Relationship between Little Tern (Sternula albifrons) timing of breeding (assessed as the \% of clutches initiated in the period 1-15 May) in Santa Luzia, Ria Formosa, Algarve, and the mean NAO index for April-May of 2002-2005 and 20082011.

mean SST for April-May was significantly negatively related with egg volume (GLM: Wald $\chi^{2}{ }_{1}=3.01, P=0.05$; parameter estimate: $\beta=-0.032 \pm 0.017$; Fig. 5). Therefore, Little Terns laid smaller eggs during years of higher SST in the adjacent marine area.

\section{Discussion}

Our study suggests an influence of winter climatic conditions (winter sea-surface temperature) on the relative occurrence of the main prey fish species (sand smelts) in the diet of Little Terns during the breeding season, which, in turn, influenced Little Tern breeding parameters (clutch size). Our results suggest also that Little Tern timing of breeding and egg size are significantly associated with spring climate fluctuations per se, as measured respectively by NAO and SST variations in April-May. NAO and SST

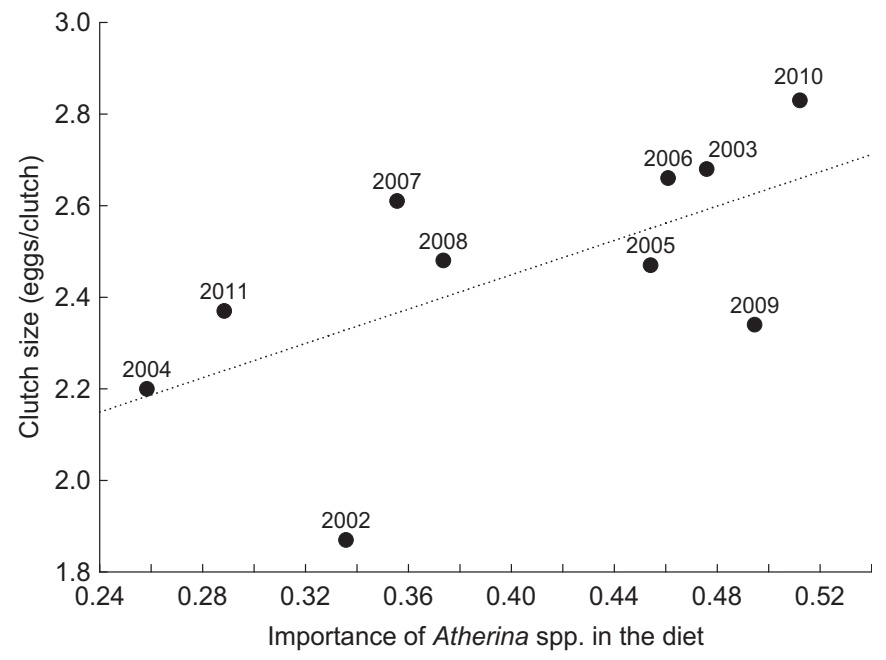

Fig. 4. Relationship between clutch size of Little Tern (Sternula albifrons) in Santa Luzia, Ria Formosa, Algarve, and the relative importance of sand smelts (Atherina spp.) in the diet of adults (=relative occurrence) in May-June of 2002-2011. To obtain the relative occurrence of sand smelts in the diet for each year, the \% of occurrence of each item was added to make $100 \%$ and the value for sand smelts was scaled in relation to this total value.

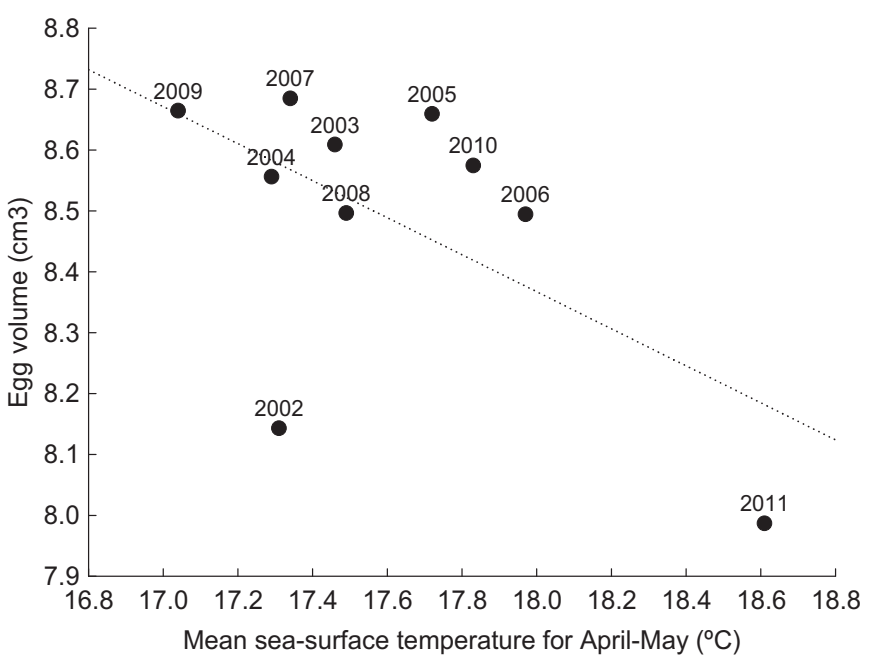

Fig. 5. Relationship between egg volume of Little Tern (Sternula albifrons) breeding in the salinas of Santa Luzia, Ria Formosa, Algarve, and the sea-surface temperature in the adjacent sea area in April-May.

integrate different environmental conditions, in particular the NAO, which is a large-scale index reflecting oceanographic and climatic conditions over the North Atlantic Ocean. It seems that spring climatic conditions over a large scale, represented by the NAO index, are important in explaining variations in timing of breeding, local SST during spring is important to explain egg size, and the abundance of sand smelts during the breeding season explains the number of eggs laid. In addition, our data suggest that during years with higher NAO and SST sand smelts might attain a smaller size, therefore energy yield per unit foraging effort will be smaller.

In the present study the only Little Tern breeding parameter correlated with NAO was timing of laying, with most birds laying later during a high NAO spring (April-May) index. This suggests that large-scale climatic conditions may affect arrival and settlement on the breeding grounds (Wanless et al., 2009). A relationship between the NAO index and seabird phenology has previously been shown for seabird species breeding in the North Sea (Frederiksen et al., 2004; Wanless et al., 2009), but it is the first time that a relationship between a large-scale climate index and seabird reproductive parameters is shown for estuarine seabirds, and for seabirds in southern Europe. Most recent studies on North Sea coastal seabirds show a delay in breeding following a low winter/ early spring NAO index (Frederiksen et al., 2004; Reed et al., 2006; Wanless et al., 2008, 2009). Our study shows the opposite for Little Terns in the Algarve. During years with a low spring NAO index foraging conditions in the North Sea may be poor for seabirds, but this threshold might not be passed further south. There was a negative trend between the winter NAO index and spring SST in our study area, but local SST could not be predicted exactly from the NAO. Other variables, such as the recent change in the NAO centre of action to the Northeast, are likely to be important (Báez et al., 2013).

Our data show that the diet of Little Tern was fairly constant between 2002 and 2011, and dominated by sand smelts. Our results suggest that during winters with lower local SST the abundance of sand smelts will be higher during the Little Tern breeding season, because egg and larval survival is favoured by a lower sea-surface temperature (Checkley et al., 1988; Ré et al., 1990). In addition, marine pelagic fish species taken by Little Terns such as sardine S. pilchardus spawn in winter/early spring along the coast when SST ranges $14-16{ }^{\circ} \mathrm{C}$ (Ré et al., 1990), and a peak of abundance of sardine late larvae occur in Ria Formosa by March/April (Chícharo 
Table 2

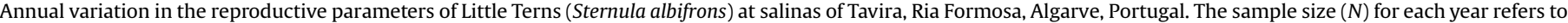
the number of completed clutches. Values for clutch size and egg measures are mean $\pm \mathrm{SD}$. Nd means no data.

\begin{tabular}{|c|c|c|c|c|c|c|c|c|c|c|}
\hline & 2002 & 2003 & 2004 & 2005 & 2006 & 2007 & 2008 & 2009 & 2010 & 2011 \\
\hline$N$ & 53 & 97 & 70 & 47 & 28 & 32 & 31 & 35 & 29 & 35 \\
\hline Clutches laid 1-15 May (\%) & 6 & 16.5 & 7.9 & 5.8 & $\mathrm{Nd}$ & $\mathrm{Nd}$ & 47.5 & 0 & 10.3 & 2.9 \\
\hline Clutch size (eggs/clutch) & $1.87 \pm 0.63$ & $2.68 \pm 0.52$ & $2.2 \pm 0.63$ & $2.47 \pm 0.66$ & $2.66 \pm 0.45$ & $2.61 \pm 0.48$ & $2.48 \pm 0.63$ & $2.34 \pm 0.69$ & $2.83 \pm 0.38$ & $2.37 \pm 0.65$ \\
\hline Egg length (mm) & $31.66 \pm 1.16$ & $32.06 \pm 0.99$ & $32.08 \pm 1.16$ & $32.50 \pm 2.68$ & $31.90 \pm 0.99$ & $32.04 \pm 0.78$ & $31.90 \pm 0.79$ & $32.08 \pm 1.21$ & $31.67 \pm 1.05$ & $31.10 \pm 0.93$ \\
\hline Egg breadth (mm) & $22.98 \pm 0.53$ & $23.48 \pm 0.47$ & $23.40 \pm 0.59$ & $23.39 \pm 0.59$ & $23.39 \pm 0.41$ & $23.6 \pm 0.48$ & $23.39 \pm 0.54$ & $23.55 \pm 0.58$ & $23.58 \pm 0.44$ & $22.96 \pm 0.58$ \\
\hline Egg volume $\left(\mathrm{cm}^{3}\right)$ & $8.14 \pm 0.53$ & $8.61 \pm 0.46$ & $8.56 \pm 0.57$ & $8.66 \pm 0.92$ & $8.49 \pm 0.36$ & $8.68 \pm 0.38$ & $8.50 \pm 0.46$ & $8.66 \pm 0.59$ & $8.57 \pm 0.47$ & $7.99 \pm 0.55$ \\
\hline
\end{tabular}

et al., 2012), just before the onset of the Little Tern breeding season. The relationship between SST and the relative importance of sand smelts in the diet of Little Terns was established with SST data for the sea area adjacent to the lagoon of Ria Formosa (Fig. 1). About $75 \%$ of the water in the lagoon is exchanged daily with the sea (Newton and Mudge, 2003) through tidal channels where the Little Terns forage (Paiva et al., 2008). Thus, we consider SST data from this location representative of the conditions found by the terns. We present this tentative explanation, because clutch size was positively associated with the proportion of sand smelts in the diet, and previously Catry et al. (2006) have shown that Little Terns consume sand smelts in direct relation to its abundance in the lagoon (measured with beach seine nets).

In subtropical areas physical conditions during winter/early spring, in particular storm-induced upwelling, favour the development of pelagic fish eggs and larvae and therefore fish recruitment (Checkley et al., 1988). Nevertheless, most studies show that seabirds are adapted to unpredictable foraging conditions and show a relatively high degree of plasticity in reproductive parameters such as timing of breeding and diet composition (Sydeman et al., 2001; Schreiber, 2002). Our data agree with this general statement, because during years with higher SST birds ate less sand smelts and more low quality prey such as crustaceans, as well as other prey that we were unable to identify. Because seabirds are long-lived species, such plasticity enables them to buffer against short-term environmental variability, especially at the population level. In fact, the Little Tern population in the Algarve has been stable over the past 20 years (Almeida et al., 2005), despite pronounced variability in food supply between years.

Our data also suggest that SST adjacent to the Ria Formosa lagoon in April/May influences the mean egg volume laid by terns, with egg volume decreasing with the increase of SST. The link between egg volume and SST in April-May should also be food supply. Our 4-year data on size of sand smelts tentatively suggest that in years with higher SST and NAO the mean mass of ingested sand smelts is lower. Therefore, the yield per unit foraging effort for the main prey species may influence both the number and the size of eggs laid. Overall, during years of lower spring SST the abundance of sand smelts might be higher and with more large-sized fishes, enabling females to produce larger eggs. A lower spring SST may be particularly important for sand smelts, because this resident species shows morphological and physiological adaptations to local conditions (Francisco et al., 2008), and should reach a larger size in locations with colder waters (Maci and Basset, 2010). Female birds appear to use stored, endogenous protein for egg production, and a high quality diet may enable them to store more protein reserves and thus produce larger eggs (Williams, 1996).

\section{Conclusion}

Our results suggest that (1) negative NAO conditions in the Atlantic Ocean (often associated with greater vertical mixing and stronger winds) influenced earlier breeding, and (2) lower SST in the surroundings of the colony during winter-spring favoured the abundance of prey fish for Little Terns in the Algarve, Southern Portugal. This, in turn, influenced their reproductive parameters, clutch size and egg size. There was a significantly positive correlation between the relative occurrence of the most important item in the diet over a decade, sand smelts, and the number of eggs laid. Birds bred earlier and laid larger eggs in years with a low spring NAO index and a lower SST, respectively. It is the first time that a relationship between large-scale climatic factors/sea conditions and reproductive parameters has been shown for estuarine seabirds. Relationships among climate patterns at different scales are changing rapidly (Edwards and Richardson, 2004), and this should have important implications for estuarine seabirds in Southern Europe.

\section{Acknowledgements}

Part of the data presented here were collected under the project POCTI/BSE/37385/2001 "Breeding and foraging ecology of Little Terns to provide ecological indicators in estuarine environments" financed by the Fundação Portuguesa para a Ciência e Tecnologia. Throughout the years several people helped in fieldwork, particularly Nuno Grade, Teresa Catry, Renata Medeiros, Jorge Palma, Ana Almeida and Nuno Lopes. We acknowledge the support given by Fundação para a Ciência e Tecnologia, Portugal, to Patricia Pedro (SFRH/BD/40095/2007). We are also grateful to Parque Natural da Ria Formosa for logistical support.

\section{References}

Almeida, J., Catry, P., Encarnação, V., Franco, C., Granadeiro, J.P., Lopes, R.J., Moreira, F., Oliveira, P., Onofre, N., Pacheco, C., Pinto, M., Pitta, M.J., Ramos, J.A., Silva, L., 2005. Aves. In: Cabral, M.J., Almeida, J., Almeida, P.R., Dellinger, T., Ferrand de Almeida, N., Oliveira, M.E., Palmeirim, J.M., Queiroz, A.I., Rogado, L., Santos-Reis, M. (Eds.), Livro Vermelho dos Vertebrados de Portugal. Instituto da Conservação da Natureza, Lisboa.

Aebischer, N.J., Coulson, J.C., Colebrook, J.M., 1990. Parallel long-term trends across four marine trophic levels and weather. Nature 347, 753-755.

Báez, J.C., Gimeno, L., Gómez-Gesteira, M., Ferri-Yáñez, F., Real, R., 2013. Combined effects of the North Atlantic oscillation and the Arctic oscillation on sea surface temperature in the Alborán Sea. PLoS One 8 (4), e62201. http://dx.doi.org/ 10.1371/journal.pone.0062201.

Becker, G.A., Pauly, M., 1996. Sea surface temperature changes in the North Sea and their causes. ICES J. Mar. Sci. 53, 887-898.

Catry, T., Ramos, J.A., Catry, I., Revez, M.-A., Grade, N., 2004. Are salinas a suitable alternative breeding habitat for Little Terns? Ibis 146, 247-257.

Catry, T., Ramos, J.A., Martins, J., Peste, F., Trigo, S., Paiva, V.H., Almeida, A., Luís, A., Palma, J., Andrade, P., 2006. Inter-colony and annual differences in the diet and feeding ecology of Little Tern adults and chicks in Portugal. Condor 108, 366376.

Checkley Jr., D.M., Raman, S., Maillet, G.L., Mason, K.M., 1988. Winter storm effects on the spawning and larval drift of a pelagic fish. Nature 335, 346-348.

Chícharo, M.A., Amaral, A., Faria, A., Morais, P., Mendes, C., Piló, D., BenHamadou, R., Chícharo, L., 2012. Are tidal lagoons ecologically relevant to larval recruitment of small pelagic fish? An approach using nutritional condition and growth rate. Estuar. Coast. Shelf Sci. 112, 265-279.

Coulson, J.C., 1963. Egg size and shape in the Kittiwake (Rissa tridactyla) and their use in estimating age composition of populations. Proc. Zool. Soc. Lond. 140, $211-227$. 
Dänhardt, A., Becker, P.H., 2011. Herring and sprat abundance indices predict chick growth and reproductive performance of common terns breeding in the Wadden Sea. Ecosystems 14, 791-803.

Duffy, D.C., Jackson, S., 1986. Diet studies of seabirds: a review of methods. Colon. Waterbirds 9, 1-17.

Edwards, M., Richardson, A.J., 2004. Impact of climate change on marine pelagic phenology and trophic mismatch. Nature 430, 881-884.

Frederiksen, M., Harris, M.P., Daunt, F., Rothery, P., Wanless, S., 2004. Scaledependent climate signals drive breeding phenology of three seabird species. Glob. Change Biol. 10, 1214-1221.

Francisco, S.M., Congiu, L., Stefanni, S., Castilho, R., Brito, A., Ivanova, P.P., Levy, A., Cabral, H., Kilias, G., Doadrio, I., Almada, V.C., 2008. Phylogenetic relationships of the North-eastern Atlantic and Mediterranean forms of Atherina (Pisces, Atherinidae). Mol. Phylogenet. Evol. 48, 782-788.

Furness, R.W., Camphuysen, C.J., 1997. Seabirds as monitors of the marine environment. ICES J. Mar. Sci. 54, 726-737.

Furness, R.W., Tasker, M., 2000. Seabird-fishery interactions: quantifying the sensitivity of seabirds to reductions in sandeel abundance, and identification of key areas for sensitive seabirds in the North Sea. Mar. Ecol. Prog. Ser. 202, 253-264.

Grémillet, D., Charmantier, A., 2010. Shifts in phenotypic plasticity constrain the value of seabirds as ecological indicators of marine ecosystems. Ecol. Appl. 20, 1498-1503.

Grosbois, V., Thompson, P.M., 2005. North Atlantic climate variation influences survival in adult fulmars. Oikos 109, 273-290.

Holloway, M., 1993. The variable breeding success of the little tern (Sterna albifrons) in South-East India and protective measures needed for its conservation. Biol Conserv. 65, 1-8.

Härkönnen, T.J., 1986. Guide to the Otoliths of the Bony Fishes of the Northeast Atlantic. Danbiu ApS. Biological Consultants, Hellerup.

Hurlbert, S.H., 1984. Pseudoreplication and the design of ecological field experiments. Ecol. Monogr. 54, 187-211.

Hurrell, J.W., Kushnir, Y., Ottersen, G., Visbeck, M.H. (Eds.), 2003. The NAO: Climate Significance and Environmental Impact. Geophysical Monograph Series, vol 134, p. 279.

Jones, P.D., Jonsson, T., Wheeler, D., 1997. Extension to the North Atlantic oscillation using early instrumental pressure observations from Gibraltar and South-West Iceland. Int. J. Climatol. 17, 1433-1450.

Maci, S., Basset, A., 2010. Spatio-temporal patterns of abundance, size structure and body condition of Atherina boyeri (Pisces: Atherinidae) in a small non-tidal Mediterranean lagoon. Estuar. Coast. Shelf Sci. 87, 125-134.

Medeiros, R., Ramos, J.A., Paiva, V.H., Almeida, A., Pedro, P., Antunes, S., 2007 Signage reduces the impact of disturbance on little tern nesting success in Portugal. Biol. Conserv. 135, 99-106.

Monticelli, D., Ramos, J.A., Quartly, G.D., 2007. Effects of annual changes in primary productivity and ocean indices on the breeding performance of tropical roseate terns in the western Indian Ocean. Mar. Ecol. Prog. Ser. 351, 273-286.

Newton, A., Mudge, S.M., 2003. Temperature and salinity regimes in a shallow, mesotidal lagoon, the Ria Formosa, Portugal. Estuar. Coast. Shelf Sci. 56, 1-13.

Nolf, D., 1985. Otolithi Piscium. In: Handbook of Paleoichthyology, vol. 10. Gustav Fisher Verlag, Stuttgart \& New York.

Paiva, V.H., Ramos, J.A., Catry, T., Pedro, P., Medeiros, R., Palma, J., 2006a. Influence of environmental factors and energetic value of food on Little Tern chick growth and food delivery. Bird Study 53,1-11.

Paiva, V.H., Ramos, J.A., Machado, D., Penha-Lopes, G., Bouslama, M.F., Dias, N., Nielsen, S., 2006b. Importance of marine prey to growth of estuarine tern chicks: evidence from an energetic balance model. Ardea 94, 241-255.
Paiva, V.H., Ramos, J.A., Martins, J., Almeida, A., Carvalho, A., 2008. Foraging habitat selection by Little Terns Sternula albifrons in an estuarine lagoon system of southern Portugal. Ibis 150, 18-31.

Piatt, J.F., Harding, A.M.A., Shultz, M., Speckman, S.G., van Pelt, T.I., Drew, G.S. Kettle, A.B., 2007. Seabirds as indicators of marine food supplies: Cairns revisited. Mar. Ecol. Prog. Ser. 352, 221-234.

Pinto, J.G., Raible, C.C., 2012. Past and recent changes in the North Atlantic oscillation. WIREs Clim. Change 3, 79-90.

Ramos, J.A., Maul, A.M., Ayrton, V., Bullock, I., Hunter, J., Bowler, J., Castle, G., Mileto, R., Pacheco, C., 2002. The influence of local and large scale weather events and timing of breeding on tropical Roseate Tern reproductive parameters. Mar. Ecol. Prog. Ser. 243, 271-279.

Ré, P., Cabral e Silva, R., Cunha, E., Farinha, A., Meneses, I., Moita, T., 1990. Sardine spawning off Portugal. Bol. Inst. Nac. Investig. Pescas 15, 31-34.

Reed, T.E., Wanless, S., Harris, M.P., Frederiksen, M., Kruuk, L.E.B. Cunningham, E.J.A., 2006. Responding to environmental change: plastic responses vary little in a synchronous breeder. Proc. R. Soc. Lond. B 273, $2713-$ 2719.

Reynolds, R.W., Rayner, N.A., Smith, T.M., Stokes, D.C., Wang, W., 2002. An improved in situ and satellite SST analysis for climate. J. Climate 15, 1609-1625.

Ribeiro, J., Monteiro, C.C., Monteiro, P., Bentes, L., Coelho, R., Gonçalves, J.M.S. Lino, P.G., Erzini, K., 2008. Long-term changes in fish communities of the Ria Formosa coastal lagoon (southern Portugal) based on two studies made 20 years apart. Estuar. Coast. Shelf Sci. 76, 57-68.

Safina, C., Burger, J., Gochfeld, M., Wagner, R.H., 1988. Evidence for prey limitation of common and roseate tern reproduction. Condor 90, 689-698.

Schreiber, E.A. 2002. Climate and weather effects on seabirds. In: Schreiber, E.A., Burger, J. (Eds.), Biology of Marine Birds. CRC Press, Boca Raton, FL, pp. 179-215.

Stenseth, N.C., Ottersen, G., Hurrell, J.W., Mysterud, A., Lima, M., Chan, K.S. Yoccoz, N.G., Adlandsvik, B., 2003. Studying climate effects on ecology through the use of climate indices: the North Atlantic oscillation, El Niño southern oscillation and beyond. Proc. R. Soc. Lond. B 270, 2087-2096.

Sydeman, W.J., Hester, M.M., Thayer, J.A., Gress, F., Martin, P., Buffa, J., 2001 Climate change, reproductive performance and diet composition of marine birds in the southern California current system, 1969-1997. Prog. Oceanogr. 49, 309-329.

Tuset, V.M., Lombarte, A., Assis, C.A., 2008. Otolith Atlas for the western Mediterranean, north and central eastern Atlantic. Sci. Mar. 72 (S 1), 7-198.

Votier, S.C., Hatchwell, B.J., Beckerman, A., McCleery, R.H., Hunter, F.M., Pellatt, J., Trinder, M., Birkhead, T.R., 2005. Oil pollution and climate effects have widescale impacts on seabird demographics. Ecol. Lett. 8, 1157-1164.

Wanless, S., Harris, M.P., Redman, P., Speakman, J.R., 2005. Low energy values of fish as a probable cause of a major seabird breeding failure in the North Sea. Mar. Ecol. Prog. Ser. 294, 1-8.

Wanless, S., Harris, M.P., Lewis, S., Frederiksen, M., Murray, S., 2008. Later breeding in Northern Gannets in the eastern Atlantic. Mar. Ecol. Prog. Ser. 370, 263-269.

Wanless, S., Frederiksen, M., Walton, J., Harris, M.P., 2009. Long-term changes in breeding phenology at two seabird colonies in the western North Sea. Ibis 151, $274-285$.

Williams, T.D., 1996. Variation in reproductive effort in female zebra finches (Taeniopygia guttata) in relation to nutrient-specific dietary supplements during egg laying. Physiol. Zool. 69, 1255-1275.

Zuria, I., Mellink, E., 2005. Fish abundance and the 1995 nesting season of the Least Tern at bahía de San jorge, Northern Gulf of California, México. Waterbirds 28, $172-180$. 